\title{
SEPARATION OF POWERS ACCORDING TO THE NEW AMENDMENTS TO THE CONSTITUTION OF GEORGIA - PROBLEMS AND PROSPECTS
}

\author{
George Goradze \\ Georgian Technical University, Faculty of Law and International Relations
}

\begin{abstract}
The article looks at the last amendments to the Constitution of Georgia. By this amendments Georgia moves into parliamentary system. However, there are some questions: Does this system comply with European standards of parliamentary system? How will this system work in Georgia? Is a parliamentary system ideal model for Post-Soviet countries and particularly for Georgia? The article is divided into two parts: The first part looks at the new redaction of the Constitution of Georgia and the new system of governance which will be established by this constitutional changes. By analysis the author comes to the conclusion that new amendments to the constitution will serve as a guarantee of a long-standing stay in the government for the ruling political party; In the second part of the article the author discusses the negative aspects of a parliamentary system in general. Here main question is "how will the Parliament control the executive branch and its leader who is the head of the ruling party and the parliamentary majority, as well? It may be vice versa." In The author' opinion one of the ways for a parliamentary system is to elect a non-party president through a universal suffrage.
\end{abstract}

Key words: Constitution of Georgia, amendments, elections, parliamentary system, parliament, government, Prime Minister, Vote of No Confidence.

\section{INTRODUCTION}

In 2017 and 2018 Parliament of Georgia made substantial amendments to the constitution of Georgia. As a result, the Constitution has changed both in terms of technique and content. The government of Georgia often mentions that providing these Constitutional amendments helps the country to move to the European Parliamentary State System - considered to be the most democratic model.

In this paper Iwill be discussed the veracity of these words concerning the Separation of Powers. First, we should find out the essence of the amendments to the Georgian Constitution and the compliance of it with European standards. Then we will turn to a broader discussion of merits and perils of the Parliamentary System and whether it represents an ideal model.

\section{ELECTIONS WITH REGARD TO CONSTITUTIONAL AMENDMENTS}

It is not arguable that the basis for any republican and democratic state is elections. "Regular and genuine elections remain the primary institutional mechanism through which rulers are made ac- 
countable to those in whose name they exercise political power... It is difficult to envision modern democracy without meaningful elections."

In this paper, I will mainly discuss the changes in electoral rules and the alleged consequences of them in respect to the principles of Separation of Powers.

First it should be emphasized that after constitutional amendments enter into force there will be some transitional period until 2024; however, the Parliamentary System will be fully enacted from 2024 onwards, as announced by the government.

Let's see what the transitional changes include. According to the new redaction ${ }^{2}$ of the constitution: ${ }^{3}$

1. In 2018 the president was elected by universal suffrage. A new rule of the presidential election will be enacted from 2024, when the powers of the President elected by universal suffrage will expire. $^{4}$

2. As before, the political parties and the unities of political parties - electoral blocks will be able to participate in a proportional voting system election. ${ }^{5}$

3. For 2020 the election threshold will be reduced one-time-only from $5 \%$ down to $3 \%{ }^{6}$

4. Finally and most importantly, the current electoral model will remain in force for the 2020 parliamentary elections. According to the model 77 members of parliament will be elected by the proportional voting system and 73 members - by the majoritarian voting system. ${ }^{7}$

It is worth mentioning that the majoritarian voting system in Georgia has always benefited the ruling party. An illustrative example of which is the current Parliament of Georgia:

In the 2016 parliamentary elections the ruling party received 856638 votes out oftotal 3513884 registered voters that is $24.37 \%$ of the total number of electorate. Accordingly, by the proportional voting system the ruling party received 44 seats in the Parliament, but by the majoritarian voting system the party received additional 71 seats from $73 .{ }^{8}$ Moreover, although the governing party did not win the other 2 seats, these seats were taken by the satellite subjects of the elections.

It is a proven fact that one of these two "independent" majoritarians - Salome Zourabichvili (current President of Georgia) has put herself as presidential candidate in the presidential elections in 2018 and the ruling party decided to support her. Therefore, the ruling party has refused to have a presidential candidate from its members and fully supported (including financial) to this "independent" candidate. Moreover, even the legislative amendments were made to the Election Code of Georgia for Salome Zurabishvili. It is clear that in the conditions of the given electoral system, talking about independent majoritarians is unnecessary.

1 ROSENFELD, M., SAJO, A. (ed.): The Oxford Handbook of Comparative Constitutional Law. Oxford : Oxford University Press, 2012, p. 529.

2 In this paper "new redaction" means current text of the Constitution of Georgia (1995) including constitutional amendments of 23 March 2018, but "old redaction" means the text of the Constitution including constitutional amendments of 04 October 2013.

3 The official text of the Constitution of Georgia you can found here: https://matsne.gov.ge/en/document/view/ 30346? publication $=35$

4 Constitution of Georgia, article 50, para. 3.

5 Constitutional Law of Georgia "About Amendment to the Constitution of Georgia" of 23 March 2018. Article 1, para. 2, available at: https://matsne.gov.ge/ka/document/view/4110673?publication $=0$.

Ibid., article 1, para. 2.

Ibid., article 1, para. 2.

Summary Protocol of the Central Election Commission of Georgia on the Final Results of 8 October 2016 Parliamentary Elections of Georgia. Tbilisi, 16 November 2016, available at: http://cesko.ge/res/docs/shemajamebelieng.pdf. 
Here may appear a simple question: Why is it happening that, in all majoritarian electoral districts the candidates of the ruling party are always winning the elections? To some extent, this question includes the answer: because they are the favorites of the ruling party, which means that they use the ruling party's resources. In particular, during their election campaign they are supported by local municipalities, representatives of law enforcement agencies and party assets. There are also big financial resources that the existing ruling party has. It is also important for the election administration in which the ruling party always has the majority.

Thus, the fact is that the ruling party, which in the parliamentary elections in 2016 collected $24.37 \%$ of electorate, obtained more than $76 \%$ of mandates in the parliament, which means that it received constitutional majority. ${ }^{9}$

Despite the demands of Venice Commission, the political spectrum of Georgia, the society and the promise of the ruling party of Georgia, that the majoritarian voting system will be abolished for the 2020 parliamentary elections, the government doesn't make concessions.

From this perspective it is clear that lowering of the threshold from $5 \%$ to $3 \%$ does not have any meaning. At first glance, it may be considered as a positive phenomenon, as it provides a broad spectrum of political parties in the legislative body of Georgia, but if you look at it well, it is more contrary. The point is that, as already noted above, by 2020, the majoritarian electoral system will remain, which ensures the preservation of the parliamentary majority for ruling party. That is, the ruling party is supposedly guaranteed by the parliamentary majority for 2020. In this case, the threshold of the election threshold will only increase between 5 to 3 percent between the opposition parties. Thus, it is only favorable for the ruling party.

Therefore, by keeping the majoritarian voting system, the Georgian governing party has guaranteed the parliamentary majority up to 2024 .

As it has been announced, from 2024 onwards the country should fully adopt the parliamentary model. Let us now consider Constitution changes in this regard:

1. The majoritarian electoral system will be abolished in the parliamentary elections and the Parliament will be composed only of the members elected by the proportional voting system; ${ }^{10}$

2. However, it seems that, as a counterweight, the unities of political parties - electoral blocks will not be able to participate in the parliamentary elections, ${ }^{11}$ and the election threshold will again rise up to $5 \% .{ }^{12}$ That is, when the country passes on a parliamentary model, which should be based on political parties and coalitions of the parties, instead of strengthening political parties, the changes serve to weaken them.

In addition, it once again confirms the above-mentioned opinion on the reduction of the electoral threshold from $5 \%$ to $3 \%$ by 2020 . If the changeswere aimed at increasing the political pluralism in the Parliament of Georgia, then the threshold would remain within 3\% for the next elections, but it is not so. From 2024 by the moving to the full proportional electoral system, when the ruling party will no longer have bonus at the expense of majoritarian electoral system, the reduced election threshold will have a negative impact for the party. That is why the election threshold will be increased up to $5 \%$ since 2024 .

\footnotetext{
9 Summary Protocol of the Central Election Commission of Georgia on the Final Results of 8 October 2016 Parliamentary Elections of Georgia. Tbilisi, 16 November 2016, available at: http://cesko.ge/res/docs/shemajamebelieng.pdf.

10 Constitution of Georgia, article 37, para. 2.

11 Ibid., article 37, para. 5.

12 Ibid., article 37, para. 6.
} 
So even the given changes also serve the ruling party in power after 2024 .

3. From 2024 onwards the President of Georgia will not be elected through universal and equal elections, but will be elected by the Board of Elections consisting of 300 electors. The rule for the board composition raises the doubt that the board will be overrepresented by the members of the ruling party. ${ }^{13}$

According to the paragraph 3 of article 50 (Procedures for electing the President of Georgia) "The Electoral College shall consist of 300 members, and shall include all members of the Parliament of Georgia and of the supreme representative bodies of the Autonomous Republics of Abkhazia and Ajara. Other members of the Electoral College shall be nominated by the respective political parties from among the representative bodies of local self-governments on the basis of quotas defined by the Central Election Commission of Georgia in accordance with the organic law. The quotas are defined in compliance with the principle of proportional geographical representation and in accordance with the results of the elections of local self-governments held under the proportional system. The composition of the Electoral College shall be approved by the Central Election Commission of Georgia."

Here the main issue is that the Electoral College, which should elect the President of Georgia, will consist of the representatives of the Parliament of Georgia, supreme representative bodies of Autonomous Republics of Abkhazia and Ajara and local self-government bodies. Same time, the Parliament of Georgia and the supreme representative bodies of the Autonomous Republics of Abkhazia and Ajara will be represented in the Electoral College.

The latest history of Georgia shows us that, with a rare exception, everywhere in the local self-governing representative bodies (Sakrebulo) majority belongs to the government party. An example of this is the current situation: After local self-government election on October 2017 from 64 local self-governing representative bodies - Sakrebulo (including Sakrebulo of capital Tbilisi) the ruling party do not have majority only in Borjomi Sakrebulo.

The same applies to the Supreme Council of the Autonomous Republic of Ajara, where the majority always belongs to the ruling party. As for the representative body of the Autonomous Republic of Abkhazia, the legitimate authority was expulsed of from this territory in early 1990-ss. From this time, the representative body of the Autonomous Republic of Abkhazia elections have not been held yet and have not been renewed. As recent history and current situation show, existing members of the representative body of the Autonomous Republic of Abkhazia, as a rule, are not distinguished with any government confrontation.

The submitted statistics show us that the Electoral College, which should elect the President of Georgia from 2024, will be consist of the majority of the ruling party.

Therefore, the President of Georgia will be elected by the ruling party

Note that the main reason why the rule of presidential elections should be changed in Georgia is that the previous president often created some discomfort to the governing party. Although in 2013 he was nominated as a presidential candidate by the ruling party, he took a relatively neutral position after being elected: disagreeing on some issues with the ruling majority and vetoing several bills. Thus, in my opinion, when the President realized that he would not be elected by people OR by any particular party, he started to act as an independent government branch - as the Head of the

13 Ibid., article 50, para. 3. 
State. Thanks to the recent constitutional amendments, the ruling party will no longer experience a trouble from the President starting from 2024.

4. Parliament will continue to elect the government under the leadership of the Prime Minister, but this will be done by the reduction of the controlling function of the Parliament of Georgia and, in general, the background of strengthening the government, especially of the prime minister's figure:

a) Article 811 paragraph one of the old redaction of the Constitution of Georgia set out: "After Parliament gives a vote of confidence in the Government and the Government Programme, if the initial composition of the Government is renewed by one third but not less than 5 members of the Government, the President of Georgia shall present a composition of the Government to Parliament for giving a vote of confidence within one week." ${ }^{14}$ According to the new redaction of the Constitution similar obligation does not exist, which means that the Prime Minister can totally change the composition of the Government practically on the next day after receiving a confidence from Parliament. In such a case, it is unclear what is the reason of a Parliament's vote of confidence in the Government if the Prime Minister can totally change its composition without Parliament? It degrades status of the supreme legislative body;

b) In accordance with article 93, paragraph 41 of the old redaction of the Constitution of Georgia, "If Parliament fails to adopt State Budget within two months after the beginning of a new budget year, this shall be regarded as raising a question of giving a vote of no confidence." By the last amendments of the Constitution, this rule is abolished and the government is no longer responsible for failure State Budget draft;

c) Regarding the State Budget, it is important to know that Parliament will not have the right to make any amendment to the budget draft without the consent of the government. Article 66, Paragraph 3 of the new redaction of the Constitution of Georgia enounces, that "Amending a draft law on the State Budget shall be inadmissible without the consent of the Government." It is true that same rule was acted before, but the transition to the parliamentary system logically had to cause its abolition and increase of parliament's power in budget issues, though this did not happen. It should be noted that the European Commission for Democracy Through Law (Venice Commission) expressed the same remarks regarding the issue. It stated: "The fact that any amendment to the Draft State budget needs governmental approval is an excessive restriction of the Parliament's powers in budget matters...The Commission thus reiterates its previous recommendation in the 2010 Final Opinion that the Parliament should be more significantly involved in budget matters." ${ }^{35}$ Despite the recommendation of such an authoritative organization, Georgian Parliament did not consider it;

d) The terms of holding a vote of no confidence in the Government have been reduced. In Georgia operates so-called Constructive Vote of No Confidence. The term the Constructive Vote of No Confidence means that the initiators shall nominate a candidate of Prime Minister together with a no confidence motion. ${ }^{16}$ According to old redaction of the Constitution of Georgia, the Parliament has to elect a new Prime Minister and Government during 25 days from proposing no confidence.

14 The official text of the old redaction of the Constitution of Georgia you can found here: https://matsne.gov.ge/en/document/view/30346? publication $=33$.

15 European Commission for Democracy Through Law (Venice Commission), Opinion on the Draft Revised Constitution, Venice, 16-17 June 2017, p. 10, available at: https://www.venice.coe.int/webforms/documents/default.aspx?pdffile=CDL$\mathrm{AD}(2017) 013-\mathrm{e}$.

16 ROSENFELD, M., SAJO, A. (ed.): The Oxford Handbook of Comparative Constitutional Law. Oxford : Oxford University Press, 2012, p. 655. 
The new redaction of the constitution has reduced this deadline to 14 days, which is very short term. For example, different dates are set by the constitutions of European countries where the institute of Constructive Vote of No Confidence acts. For example, in the same case, the Basic Law of Federal Republic of Germany does not establish the term at all. The main thing is that 48 hours have to pass since the announcement of the new chancellor. ${ }^{17}$ The same is required by the Constitution of the Republic of Slovenia, ${ }^{18}$ but the Constitution of Republic of Poland states: "A motion to pass a resolution... may be put to a vote no sooner than 7 days after it has been submitted." 19

e) By the recent amendments to the Constitution, "The Prime Minister shall have the right to present to Parliament an issue of confidence in the Government," ${ }^{20}$ but the deadlines are too limited in this case. In particular, according to the article 58, paragraph two of the new redaction of the constitution, "An issue of confidence shall be put to vote no earlier than the 7th day and no later than the 14 th day after it has been presented. If the Government fails to achieve a vote of confidence from Parliament, the President of Georgia shall, no earlier than the 8th day and no later than the 14th day after the vote, dissolve Parliament and call extraordinary parliamentary elections." ${ }^{21}$ In addition, paragraph 3 of the same article states: "The President of Georgia shall not dissolve Parliament if, within 7 days after voting against a vote of confidence in the Government, Parliament passes by a majority of the total number of its members a vote of confidence in the Government proposed by a candidate for the office of Prime Minister nominated by more than one third of the total number of the Members of Parliament." 22 So paragraphs 2 and 3 of Article 58 of new redaction of the Constitution say that if Parliament does not declare confidence in the period of 7 to 14 days, it remains only 7 days to elect a new Prime Minister. Otherwise, the President will dissolve the Parliament.

If we again draw parallels to the Basic Law of Federal Republic of Germany and the Constitution of the Republic of Slovenia, we will see that these terms are too small. For example, in accordance with Article 68, paragraph one of the Basic Law of the Federal Republic of Germany, "If a motion of the Federal Chancellor for a vote of confidence is not supported by the majority of the Members of the Bundestag, the Federal President, upon the proposal of the Federal Chancellor, may dissolve the Bundestag within twenty-one days. The right of dissolution shall lapse as soon as the Bundestag elects another Federal Chancellor by the vote of a majority of its Members." ${ }^{23}$ In such a way, after voting against a vote of confidence initiated by the Chancellor, Bundestag has 21 days to elect a new Chancellor. In accordance with Article 117 of the Constitution of the Republic of Slovenia, the National Assembly has 30 days to vote against confidence and elect a new leader. ${ }^{24}$ The Constitution of the Republic of Poland does not state any date in the same case. ${ }^{25}$

17 Basic Law for the Federal Republic of Germany, 1949, last amended of 23 December 2014, article 67. Available at: https:// www.gesetze-im-internet.de/englisch_gg/.

18 Constitution of the Republic of Slovenia, 1991, last amended of 24 May 2013, article 116. Available at: http://www.us-rs. si/media/constitution.pdf.

19 The Constitution of the Republic of Poland, 1997, article 158, para. 2. Available at: http://www.sejm.gov.pl/prawo/konst/ angielski/kon1.htm.

20 Constitution of Georgia. Article 58, para. 1.

21 Ibid., Article 58, para. 2.

22 Ibid., Article 58, para. 3

23 Basic Law for the Federal Republic of Germany, 1949, last amended of 23 December 2014, Art. 68. Available at: https:// www.gesetze-im-internet.de/englisch_gg/.

24 Constitution of the Republic of Slovenia, 1991, last amended of 24 May 2013, art. 117. Available at: http://www.us-rs.si/ media/constitution.pdf.

25 The Constitution of the Republic of Poland, 1997, art. 160. Available at: http://www.sejm.gov.pl/prawo/konst/angielski/ kon1.htm. 
Thus, the new redaction of the Constitution of Georgia has a very short term for the Parliament to declare no confidence. If by the initiative of Prime Minister the Parliament declares no confidence in the Government, but fails to elect a new Prime Minister in the time of 7 days, the President will dismiss the Parliament. Consequently, in the present case, the voting against vote of confidence in the Government is associated with a very high risk and may result in dismissal of the Parliament.

f) The Prime Minister's power has also increased in the field of defence: Until now, the President of Georgia could make a decision about using military forces during the peace and martial law, but he had top resent the decision to Parliament for approval within 48 hours after it was made. ${ }^{26}$ According to the Article 70, paragraph 6 of the new edition of the Constitution, "The Defence Forces shall act by the orders of the Minister of Defence in accordance with the procedures established by law and, during a state of emergency or martial law, by the orders of the Prime Minister." ${ }^{27}$ Moreover, article 72 paragraph one states that "Decisions on the use of the Defence Forces during martial law shall be made by the Prime Minister and shall not require Parliament's approval." Like this, according to the third sentence of the paragraph 2 of same article the Prime Minister's decisions on the use of Defence Forces during natural or technogenic disasters or epidemics do not require Parliament's approval, ${ }^{28}$ as well. Consequently, the Prime Minister's power has increased so much in the field of defense that he exceeded even the powers of President in the so-called half-presidential system how Georgia was before.

5. Actually the Chairperson and judges of the Supreme Court should be elected by the "oneparty" Parliament; (It was the case in the old redaction as well)

6. The Constitutional Court of Georgia consists of 9 members who shall be appointed/elected by the President, the Parliament and the Supreme Court in the amount of 3-3 members on parity basis. (It was the case in the old redaction as well)

\section{Let us summarize the above-mentioned changes:}

The ruling party which has the majority in the Parliament and local self-government level, guaranteed by the electoral system, elects the President, the Government, the Supreme Court members, and the Constitutional Court together with the elected President and the Supreme Court. Thus, the head of the state and the three branches of the government will be composed by one party. Since in Georgia the existing parties are mainly focused on a particular leader and are managed by them, the Georgian model of Separation of Powers provides the way to establish informal governance in the country.

The analysis above reveals that it is difficult to evaluate these changes as a transition to the European-type of the parliamentary republic. As shown, above the head of the state, legislative, executive and judicial branches may be composed by one political party. All this runs against the principle of Separation of Powers, which means that all government powers should not be concentrated in the hands of one person or one body. In Georgia situation may be even worse - power may fall in the hands of the governing party leader, who may not hold any official post. Apart from this, what is the difference between the Soviet totalitarian state and the democratic republic, if in both cases one particular party will be the main ruler and will control all three governmental branches?

Constitution of Georgia, old redaction. Article 100, par. 1.

Constitution of Georgia, article 70, par. 6.

28 Ibid., article 70, par. 2. 


\section{PERILS OF THE PARLIAMENTARY SYSTEM}

Now let us turn to the second issue: Is the parliamentary republican model so ideal? Is the principle of Separation of Powers secured in the parliamentary model and does the leading role belong to the parliament in the given system?

At the end of the twentieth century, about this issue András Sajó in his famous paper "Limiting Government: An Introduction to Constitutionalism" - wrote: In parliamentary systems "the executive has made its operations considerably independent and has become dominant without parliamentary direction. In addition, it is able to influence the legislation and the parliament's other activities that are in theory aimed at directing the executive. In other words, the executive operates by using the parliament as the formal director of its actions." ${ }^{29}$ Furthermore, the author adds that "British parliamentarism has evolved into a democratic cabinet dictatorship, and most of the nonpresidential democracies in Eastern Europe... are moving rapidly in this direction." 30 These words of Sajó are especially remarkable for those post-soviet states which have chosen Parliamentarian model as a form of governance.

Sajó ironical criticized modern parliamentary system. He says: "In parliamentary systems, the relationship between the legislative and executive branches is more fluid, including the worrying situation when it is the tail that wags the dog, that is, the executive, or the government (as the core of the executive is called on the Continent), dictates to the parliament. In some states there is no dog, only its tail, in which case the government does not even bother to ask the parliament what kind of policy it should follow." ${ }^{31}$

In the same paper, the author expresses his opinion that "British parliamentarism has evolved into a democratic cabinet dictatorship, and most of the nonpresidential democracies in Eastern Europe are moving rapidly in this direction." ${ }^{2}$ These words of Sajo are especially remarkable for the post-Soviet states who have chosen a parliamentary model as the form of governance.

Not only Sajó talks about the abovementioned tendencies of parliamentary system. Gustavo de Andrade also draws attention to this issue. He warnS against the actual merge of legislative and executive branches in parliamentary models. ${ }^{33} \mathrm{He}$ says, "Many countries in Europe adopted the parliamentary system of government as an outcome of legislative supremacy. In these systems, a considerable and important part of the executive powers is placed into the hands of a prime minister, who is usually a member of the legislative branch. Therefore, in the parliamentary systems of Europe there is no strict separation of powers since some of the executive and legislative powers merge in the hands of a prime minister." ${ }^{34}$

Georgian scientist Karlo Godoladze speaks about primate of government's competence in budget issues. He says, "If we make a practical review, we conclude that the so essential function, as a budg-

29 SAJO, A. Limiting Government : An Introduction to Constitutionalism. Budapest : Central European University Press, 1999, p. 91.

30 Ibid, p. 4

31 Ibid, p. 173

32 Ibid, p. 4.

33 De ANDRADE G. F. Comparative Constitutional Law: Judicial Review. In Journal of Constitutional Law. Vol. 3 , Iss. 3 (2001), p. 977-984. Available at: https://scholarship.law.upenn.edu/cgi/viewcontent.cgi?article=1436 \& context=jcl.

34 Ibid., p. 984 
etary competence is, realize the executive branch, but the legislation branch retains only formal competence."35

Entin thinks, "Now governments are not just a parliamentary policy executors, but they made as a main source of policy determination for parliament. That is why governments are already called not "executive" but "governor branch."36

What is the reason of this?

I believe that the primary reason of this danger is the political party's influence and role in parliamentary systems. The need for party politics and discipline tradition has brought the new government-parliament relations to the new frame. ${ }^{37}$

It is well known that, in the parliamentary system a political party which has won in the parliamentary elections composes the government, whose head, Primer-Minister, is a leader of the party. A simple question arises: How will the Parliament control the executive branch and its leader who is the head of the ruling party and the parliamentary majority, as well? It may be vice versa.

In the countries with a long democratic tradition this matter may be less problematic because of the internal party democracy and frequent practices of coalition governments. However, in Georgia, as in general in the post-Soviet states, the affairs are different. First of all, as it was mentioned above, each political party is associated with a particular leader, united around one particular person and governed by him/her. Secondly, in most cases the single party has the parliamentary majority and practically, it seldom has a coalition government. In contrast to Western European democracies, the threats coming from one-party Parliament and government in the case of Georgia is appear extremely dangerous.

However, it should be noted that the existence of the single-party parliament and the single-party government is the problem not only for the countries of new democracy. As modern American scholar Mark Tushnet remarks: "Representatives of the executive power and legislators, who are members of one political party, as a rule, will support each other except for special cases."38 Tushnet argues that such support may include covering a crime connected with corruption or even hindering the investigation. ${ }^{39}$

If Tushnet sees the problem in the presidential system where a hard model of Separation of Powers operates, then the parliamentary system seems much more problematic.The above-mentioned defects may not be revealed where a single party cannot win a majority in the Parliament, thus a coalition government is formed; the head of the coalition government is not a party leader of the parliamentary majority and thus, such parliament is more likely to exercise control over the government.

35 GODOLADZE, K. Constitutional amendments in Georgia. Political and legal aspects. De-Parliamentaryization: Myth or Reality. Tbilisi : Ilia State University, 2013, p. 63.

36 ENTIN, L. Separation of Powers: The experience of modern states (in Russian), 1995, p. 91. From: JIBGASHVILI, Z. President's Institution in Georgia and in Former Socialist Countries of Europe (Comparative Analysis). Doctoral Dissertation (in Georgian), Tbilisi State University, 2017, p. 62. Available at: http://press.tsu.ge/data/image_db_innova/ disertaciebi_samartali/zurab_jibgashvili.pdf

37 JIBGASHVILI, Z. President's Institution in Georgia and in Former Socialist Countries of Europe (Comparative Analysis). Doctoral Dissertation (in Georgian), Tbilisi State University, 2017, p. 62. Available at: http://press.tsu.ge/data/image_db_innova/disertaciebi_samartali/zurab_jibgashvili.pdf.

38 TUSHNET, M. Advanced Introduction to Comparative Constitutional Law (in Georgian). Tbilisi: Edward Elgar Publishing, 2016, p.142 - 143

39 Ibid., p. 143. 


\section{$4 \quad$ CONCLUSION}

To summarize the argumetns made in the paper I would like to note that:

1. The analysis reveals that new amendments to the constitution of Georgia will not provide the condition for the country transition to the European parliamentary system; it will serve as a guarantee of a long-standing stay in the government for the ruling political party;

2. As for the second issue, I think one of the ways for a parliamentary system is to elect a nonparty president through a universal suffrage. In the republic there must be a post elected through a universal suffrage. In such a case, the president will indeed play the role of an objective arbiter. In addition, such a president may be entitled to recruit a special body or appoint a special prosecutor who will investigate the crimes committed by high-ranking officials.

\section{Bibliography:}

De ANDRADE G. F. Comparative Constitutional Law: Judicial Review. In Journal of Constitutional Law. Vol. 3, Iss. 3 (2001), p. 977 - 984. Available at: https://scholarship.law.upenn.edu/cgi/viewcontent.cgi?article=1436\&context=jcl.

European Commission for Democracy Through Law (Venice Commission), Opinion on the Draft Revised Constitution, Venice, 16-17 June 2017. Available at: https://www.venice.coe.int/webforms/documents/default.aspx?pdffile $=$ CDL-AD(2017)013-e.

GODOLADZE, K. Constitutional amendments in Georgia. Political and legal aspects. De-Parliamentaryization: Myth or Reality. Tbilisi : Ilia State University, 2013, ISBN 978-9941-18-149-8.

JIBGASHVILI, Z. President's Institution in Georgia and in Former Socialist Countries of Europe (Comparative Analysis). Doctoral Dissertation (in Georgian), Tbilisi State University, 2017. Available at: http://press.tsu.ge/data/image_db_innova/disertaciebi_samartali/zurab_jibgashvili.pdf

ROSENFELD, M., SAJO, A. (ed.): The Oxford Handbook of Comparative Constitutional Law. Oxford : Oxford University Press, 2012, ISBN 978-0-19-957861-0

SAJO, A. Limiting Government : An Introduction to Constitutionalism. Budapest : Central European University Press, 1999, ISBN 9780585058481.

Summary Protocol of the Central Election Commission of Georgia on the Final Results of 8 October 2016 Parliamentary Elections of Georgia. Tbilisi, 16 November 2016. Available at: http://cesko.ge/res/docs/shemajamebelieng.pdf.

TUSHNET, M. Advanced Introduction to Comparative Constitutional Law (in Georgian). Tbilisi: Edward Elgar Publishing, 2016, ISBN 978-9941-18-253-2.

\section{Constitutions and Constitutional Law:}

Basic Law for the Federal Republic of Germany, 1949, last amended of 23 December 2014. Available at: https://www. gesetze-im-internet.de/englisch_gg/.

Constitution of Georgia, 1995, last amended of 04 March 2018. Available at: https://matsne.gov.ge/en/document/ view/30346.

The Constitution of the Republic of Poland, 1997. Available at: http://www.sejm.gov.pl/prawo/konst/angielski/kon1.htm. Constitution of the Republic of Slovenia, 1991, last amended of 24 May 2013. Available at:

http://www.us-rs.si/media/constitution.pdf.

Constitutional Law of Georgia "About Amendment to the Constitution of Georgia" of 23 March 2018. Available at: https://matsne.gov.ge/ka/document/view/4110673?publication=0. 


\author{
Contact information: \\ Dr. George Goradze \\ g.goradze@gtu.ge \\ Georgian Technical University \\ \# 77 Kostava str. \\ Postal code: 0160 \\ Tbilisi \\ Georgia
}

